\title{
Clostridium 属芽胞の耐熱性に及ぼす有機酸の影響†
}

\author{
山本 泰* ・今泉 渉* ・東 和男 ${ }^{*}$ - 好井久雄 ${ }^{*}$ \\ Effects of Organic acids on Thermal Resistance of Clostridium Spores
}

(Studies on Growth Inhibition of Food Spoilage Microorganisms for Low Salt Foods Part IX)

\author{
Yasushi Yamamoto*, Wataru Imaizumi* ${ }^{*}$ Kazuo Higashi* and Hisao YoshiI ${ }^{*}$ \\ * Department of Brewing and Fermentation, Tokyo University of Agriculture, \\ 1-1-1, Sakuragaoka, Setagaya-ku, Tokyo 156
}

\begin{abstract}
Effects of various organic acids on thermal resistance of spores of Clostridium botulinum $62 \mathrm{~A}$ and $213 \mathrm{~B}$, Clostridium sporogenes PA 3679 and Clostridium perfringens JCM 01382 were investigated. Thermal resistance of all the tested Clostridium spores was maximum at pH 7.0 and it decreased with increasing acidity or alkality. In particular, it was remarkable in acidic side. The addition of $0.2 \sim 0.5 \%$ adipic acid at $\mathrm{pH} 5.5 \sim 9.0$ decreased thermal resistance of spores with increasing concentration of adipic acid. Decreases of thermal resistance of $C$. botulinum and $C$. perfringens spores by addition of adipic acid were almost not affected by $\mathrm{pH}$. However, that of $C$. sporogenes spores increased as $\mathrm{pH}$ droped. The addition of $0.2 \%$ of acetic, adipic, lactic, maric, citric, fumaric, gluconic, tartaric, succinic, sorbic or propionic acid at $\mathrm{pH} 7.0$ and 9.0 decreased thermal resistance of C. botulinum $62 \mathrm{~A}$ spore by $35 \sim 65 \%$. At $\mathrm{pH} 5.5$, the decreasing actions of most of the tested organic acids on thermal resistance of $C$. botulinum $62 \mathrm{~A}$ spores were significantly reduced or disappeared, although those of adipic and acetic acid were powerful.

(Received Aug. 8, 1989)
\end{abstract}

アジピン酸は各種の細菌に対して強い生育抑制作用を

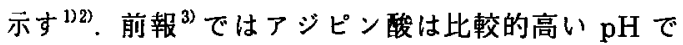
Clostridium 属株の生育を阻止するとともに芽胞の耐 熱性を低下させることを報告した．細菌や芽胞の耐熱性 は培地等の加熱時に接触している媒体成分に影響される ことから，食品に添加される各種の薬敦にっいて微生物 の加熱損傷に及ばす影響が研究されている゙） 5). 食品に 利用される酸味料としては，Salmonella typhimurium に対する酢酸得) 及び乳酸的，Clostridium 属芽 胞に対するアスコルビン酸名，Bacillus 属芽胞に対す るクエン酸ナトリゥム ${ }^{97}$, リンゴ酸10)，酢酸全，クエン 酸 ${ }^{10)}$ 及び乳酸10)についての報告がみられるすのの，他 の有機酸類の作用については殆じ知られていない. 本報では，Clostridium 属芽胞を対象として，アジ
ピン酸を中心に食品への添加が認められている各種の有 機酸類の耐熱性低下作用を $\mathrm{pH}$ との関係で検討した。

\section{実 験 方 法}

\section{1. 供試菌株}

前報”之同一の菌株を使用した。

\section{2. 嫌気培童}

前報了）と同一の方法によった.

\section{3. 有機酸}

食品への添加が許可された酸味料としてアジピン酸, 酢酸，乳酸，グルコン酸，DL-リンコ酸，酒石酸，コ八 ク酸,フマル酸及びクェン酸，保存料としてプロピオン 酸よソルビン酸を用いた（いずれる市販の特級又は一級 試薬).

†低食塩化食品における腐敗微生物の抑制に関する研究（第 9 報）（前報，文献 3$) ）$

* 東京農業大学農学部醀造学科（干156 東京都世田谷区桜丘 1-1-1） 

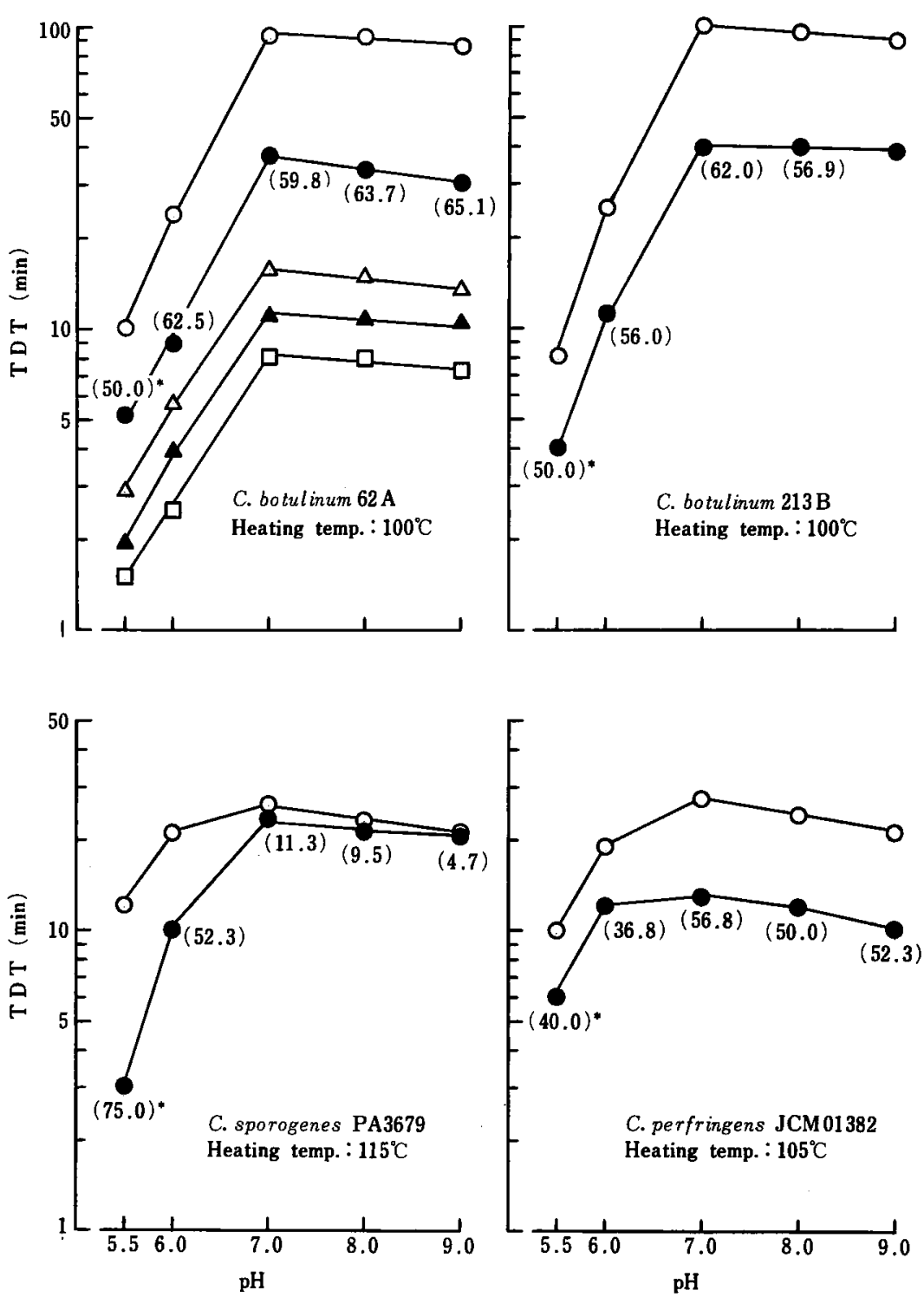

Fig. 1 Effects of $\mathrm{pH}$ on decrease of TDT of Clostridium spores by adipic acid

Clostridium spores were suspended into $1 / 15 \mathrm{M}$-phosphate buffer solutions with various $\mathrm{pH}$ containing adipic acid. Concentration of spores was $10^{5} / \mathrm{ml}$. Zero point five $\mathrm{ml}$ of the spore suspensions were pipetted into glass tubes with $5 \mathrm{~mm}$ inside diameter and it was sealed by flame under sterile conditions. Several glass tubes were heated for $1 \mathrm{~min}$ intervals at the prescribed temperatures. Zero point one $\mathrm{ml}$ of that spore suspensions were inoculated into GAM broth and cultivated in gaspak unaerobic jar (BBL) for 5 days at $30^{\circ} \mathrm{C}$. TDT was determined by the minimum heating times $(\mathrm{min})$ which growth was not recognizable.

* Decreasing rates (\%) of TDT are shown in parenthesis.

Adipic acid (\%) : $-\mathrm{O}-0,-0.2,-\triangle-0.3,-\mathbf{\Delta}-0.4,-\square-0.5$ 


\section{4. 芽胞督濁液の調製}

前報》と同一の方法によった。

5. 加熱処理及ひ加熱致死時間

前報音と同一の方法によった。

\section{実験結果及ひ考察}

\section{1. アジピン酸の耐第性低下作用に及ぼす $\mathrm{pH}$ の影留}

アジピン酸を含む $\mathrm{pH}$ 5.5 9.0のリン酸䌅衝液中に 愻濁した Clostridium 属芽胞の TDT を Fig. 1 に示 した．一般に細菌や芽胞は中性付近で最高の耐熱性を示 すことが知られている ${ }^{11}$. 本報においてあ供試菌芽胞の 耐第性は $\mathrm{pH} 7.0$ で最高となり, 酸性又はアルカリ性 になるほど低下したが，特に酸性 $\mathrm{pH}$ での低下が著し かった. いずれの芽胞もアジピン酸濃度の増加に伴って 耐熱性は低下したが，pHの影響は Clostridium botulinum $62 \mathrm{~A}$ について示したように0.2 0.5\% ア ジピン酸で同じ傾向が認められたので，他の株では 0.2 \%添加についてのみ記載した。 アジピン酸の添加に伴 う TDT 低下率” は，C. botulinum 62 A 及び 213 B では $\mathrm{pH} 5.5$, Clostridium perfringens では $\mathrm{pH} 6.0$ 以下でわずかに減少したものの他の試験 $\mathrm{pH}$ 域では大 差はなく，アジビン酸の耐熱性低下作用に及ぼす $\mathrm{pH}$ の影響は殆ど認められなかった。しかし，Clostridium sporogenes の TDT 低下率はアルカリ性 $\mathrm{pH}$ で減少 し、酸性 $\mathrm{pH}$ ほど増加する傾向がみられた。 $\mathrm{pH} 5.5$ に おける $0.2 \%$ アジピン酸溶液の非解離型分子は 5.8 $\mathrm{mg} / 100 \mathrm{ml}$ で, これは本菌に対するアジピン酸の MIC でもあり，TDT の低下に非解離型分子が関与している ことも考えられた。しかし，pH 6.0 における非解離型 分子は $0.8 \mathrm{mg} / 100 \mathrm{ml}$ で, $\mathrm{pH} 5.5$ に比べて $14 \%$ しか 存在しないが，TDT 低下率は 50\% 以上を示している こと，他の株では低下率が逆に酸性 $\mathrm{pH}$ で小さく，非 解離型分子の存在しない中性〜アルカリ性 $\mathrm{pH}$ で大き くなっていることなどから非解離型分子は芽胞の耐熱性 低下に関与しないと判断された. C. sporogenes PA 3679 は C. botulinum よりも耐熱性が強く非病原性の ため，加熱殺菌条件選定のための指標菌 ${ }^{12)}$ として使用 されているが，本実験に用いた PA 3679 は C. botulinum に比べて耐酸性が弱く ${ }^{3}$ ，低 $\mathrm{pH}$ ほど酸に対す る感受性が高まることが TDT 低下率に影響したもの と推察された，アジピン酸の C. botulinum 芽胞に対 する耐熱性低下作用は前述のように $\mathrm{pH} 5.5$ 以上では 殆ど $\mathrm{pH}$ の影響を受けないので，本菌芽胞の殺菌にア ジピン酸を利用する場合は $\mathrm{pH} 7.0$ に比べて耐熱性が
およそ $1 / 10$ に低下する $\mathrm{pH} 5.5$ で実施するのが最も効 果的であるといえる。

\section{2. 耐熱性に及ぼす各種有機酸の影㸷}

上述のようにアジピン酸は $\mathrm{pH}$ 5.5〜9.0において芽 胞の耐熱性を低下させるが，他の有機酸類においても同 様の作用肪認められるか否かを知るため，C. botulinum $62 \mathrm{~A}$ 芽胞を対象として, 各種有機酸の耐熱性低 下作用を検討した（Fig. 2，Table 1)。試験 $\mathrm{pH}$ は $5.5 ， 7.0$ 及び 9.0 とし，濃度はいずれも $0.2 \%$ とした。 $\mathrm{pH} 7.0$ と9.0における TDT の低下率は 35 65\%の 範囲で, 全ての有機酸で TDT の低下が認められた。 抗菌力を有する有機酸類の中でアジピン酸と酷酸は最む 強い低下作用を示したものの，プロピォン酸やソルビン 酸の作用は弱かった. $\mathrm{pH} 5.5$ では全ての有機酸の耐熱 性低下作用は明らかに弱まる傾向にあり，プロピオン酸， ソルビン酸，コハク酸及びクエン酸ではその作用は消失 した.しかし、アジピン酸は䤀酸とともになお50\%の TDT 低下率を示し，いずれの $\mathrm{pH} に$ において供試有機 酸中では最も強い芽胞耐熱性低下作用を示すことが明ら かとなった

有機酸類の抗菌力は非解離型分子の濃度によって規定 されるため，解離定数の小さな酸ほど強力であるが，芽 胞の耐熱性低下作用は解離定数の小さなプロピオン酸や

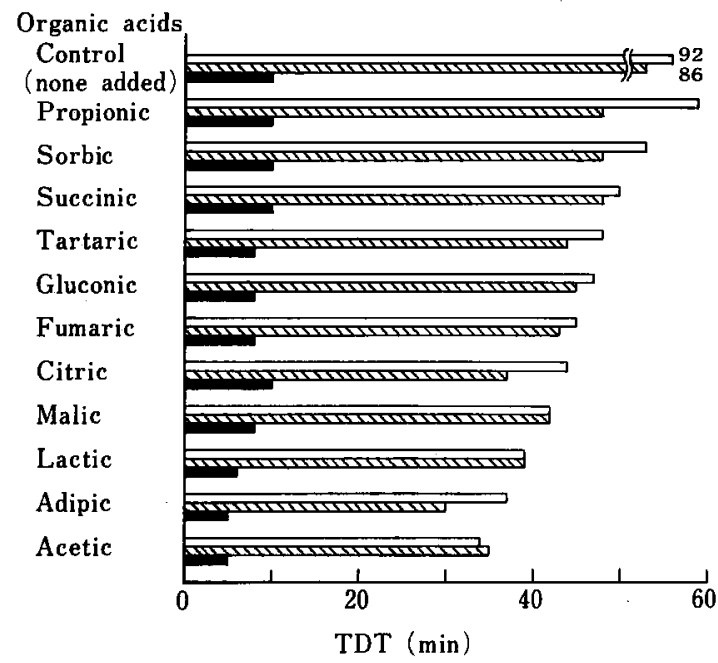

Fig. 2 Effects of organic acids on TDT of C. botulinum $62 \mathrm{~A}$ spores

Initial spores: $10^{4}$, Heating temperature: $100^{\circ} \mathrm{C}$, Organic acids concentration : $0.2 \%$, $\mathrm{pH}: \square$ 7.0, 5.0 , 5.5 
Table 1 Decreasing rates (\%) of TDT of $C$. botulinum $62 \mathrm{~A}$ spores by the addiion of $0.2 \%$ organic acids

\begin{tabular}{lrrr}
\hline & \multicolumn{3}{c}{$\mathrm{pH}$} \\
\cline { 2 - 4 } Organic acids & 5.5 & 7.0 & 9.0 \\
\hline Propionic & 0 & 35.9 & 44.2 \\
Sorbic & 0 & 42.3 & 44.2 \\
Succinic & 0 & 45.7 & 44.2 \\
Tartaric & 20.0 & 47.8 & 48.8 \\
Gluconic & 20.0 & 48.9 & 47.7 \\
Fumaric & 20.0 & 51.1 & 50.0 \\
Citric & 0 & 52.2 & 57.0 \\
Maric & 20.0 & 54.3 & 51.2 \\
Lactic & 40.0 & 57.6 & 54.7 \\
Adipic & 50.0 & 59.8 & 65.1 \\
Acetic & 50.0 & 63.0 & 59.3 \\
\hline
\end{tabular}

ソルビン酸で弱いなど，必ずしす解離度との関係は認め られなかった。また，その作用は酸性 $\mathrm{pH}$ よりも中性 〜アルカリ性 $\mathrm{pH}$ の方が強く，この点から屯非解離型 分子の関与は否定される結果となった，加熱による細胞 や芽胞の死滅は細胞壁や細胞膜 (又は胞子膜) 等の表層 構造の損傷及びリボソーム，RNA，DNA，醅素等の内 部成分の変性等に起因すると考えられるが，有機酸の種 類による耐熱性低下作用の差は，これらの損傷や变性等 の促進作用が個々の有機酸によって異なるためと推測さ れるので，この点については現在引続き検討中である.

\section{要約}

Clostridium 属芽胞を対象として，アジピン酸を中 心に各種有機酸類の耐熱性低下作用を $\mathrm{pH}$ との関係で 検討した。

（1）いずれの供試芽胞も耐熱性は $\mathrm{pH} 7.0$ で最高と なり，酸性又はアルカリ性になるほど低下したが，特に 酸性での低下が著しかった。

（2）アジピン酸の芽胞耐熱性低下作用は $\mathrm{pH} \mathrm{5.5〜}$
9.0 のいずれにおいても濃度の增加に伴って增强された。

（3） アジビン酸の芽胞耐熱性低下作用は C. botulinum よ C. perfringens ではそれぞれ $\mathrm{pH} 5.5$ と 6.0 以下で若干減少したものの殆ど $\mathrm{pH}$ の影響は受けな かった．しかし，C. sporogenesでは低 $\mathrm{pH}$ ほどその 作用は增強された。

（4）供試有機酸はいずれも $\mathrm{pH} 7.0$ 及び 9.0 におい $\tau$ C. botulinum $62 \mathrm{~A}$ 芽胞の耐熱性を 35 65\% 低下 させた. $\mathrm{pH} 5.5$ では大部分の有機酸の耐熱性低下作用 は減少し. プロピオン酸, ソルビン酸, コハク酸及びク エン酸ではその作用は消失した，しかし，アジピン酸と 酢酸はなお強力な耐熱性低下作用を示した。

\section{文献}

1）山本 泰 - 俥部則夫 - 東 和男 - 好井久雄：日食 工誌, 34, 88 (1987).

2）山本 泰 -三澤泰彦-東 和男 - 好井久雄 : 日食 工誌，36，62 (1989).

3）山本 泰・小野尚之-東 和男・好井久雄：日食 工誌, 36, 551 (1989).

4) 土戸哲郎：酸酵工学， 55，144 (1977).

5）芝崎 勲：新 - 食品殺菌工学 (光琳- 東京), p. 390 (1983).

6) Lategan, P.M. and VAughn, R.H.: $J$. Food Sci., 29, 339 (1964).

7) Garibaldi, J.A. : Food Technol., 22, 1013 (1968).

8) Eller, C., Edwards, F.F. and WynNe, E.S. : Appl. Microbiol., 16, 349 (1968).

9）犬飼 進 - 菊池順子 - 渡刃忠雄 : 食衙誌，25, 125 (1984).

10) Lynch, D.J. and Potter, N.N.: J. Food Prot., 51, 475 (1988).

11）芝崎 勲：新- 食品殺菌工学，（光琳-東京） p. 26 (1983).

12）芝崎 勲: 新 - 食品殺菌工学, (光琳- 東京) p. 36 (1983).

(平成元年 8 月 8 日受理) 